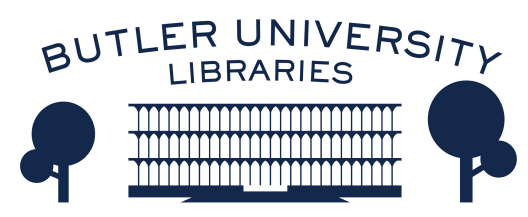

Journal of Hindu-Christian Studies

Volume 20

Article 9

January 2007

\title{
Loving God as a Devoted Servant
}

John B. Carman

Follow this and additional works at: https://digitalcommons.butler.edu/jhcs

Part of the Religion Commons

\section{Recommended Citation}

Carman, John B. (2007) "Loving God as a Devoted Servant," Journal of Hindu-Christian Studies: Vol. 20, Article 9.

Available at: https://doi.org/10.7825/2164-6279.1384

The Journal of Hindu-Christian Studies is a publication of the Society for Hindu-Christian Studies. The digital version is made available by Digital Commons @ Butler University. For questions about the Journal or the Society, please contact cbauman@butler.edu. For more information about Digital Commons @ Butler University, please contact digitalscholarship@butler.edu. 


\title{
Loving God as a Devoted Servant
}

\author{
John B. Carman \\ Harvard University
}

THESE three papers explore important facets of a central topic in comparing Hindu and Christian traditions: human love of God, which is related to the even broader topic of divine love for human beings. I had hoped that each of the authors would make some connections with the other two papers and thereby contribute to one or more imaginary dialogues. Since they have not done so, I shall try to link the aspects of Western and Indian traditions on which they touch, giving particular attention to the one explicitly comparative paper, that by Martin Ganeri:

In a previous version of his paper, Ganeri expressed his hope to contribute to "a more explicit encounter between the Christian and Hindu traditions . . . a form of inter-religious dialogue, in which there is a conversation of a sort between the two accounts" of Aquinas and Rāmānuja. An imagined encounter between persons in different religious traditions can approach genuine dialogue only if the author doing the imagining identifies with one tradition or the other. Ganeri is clearly writing as one belonging to the tradition of Thomas Aquinas, and therefore he is a participant in dialogue. In contrast, many modern academic comparisons are explicitly or implicitly from outside the traditions in the encounter. Such comparisons are not dialogues, but they may be helpful to those engaged in dialogues.
In the case Ganeri is exploring, the problem is how to make the comparison as full as possible, bringing in the many dimensions and multiple traditions that are joined in the two religious persons being compared. It is usually easier to do this in looking at the person in one's own tradition. A Roman Catholic thinker is heir to many of the traditions on which Aquinas drew, including Biblical interpretation, Greek philosophy, Roman law, western Catholic theology, and monastic piety. A Srivaishnava thinker, likewise, acknowledges at least three major sources of Ramanuja's thought: .Vedantic interpretation of Hindu scriptures in Sanskrit, community interpretation of the Alvars' Tamil hymns of devotion, and the Sanskrit texts of public and esoteric ritual practice, especially as handed down in the Pancaratra tradition. Modern Western studies of Ramanuja have often concentrated on the Vedantic tradition, which is the one explicit in Ramanuja's own writings.

What understanding of Ramanuja's teaching should be compared with the teaching of Thomas Aquinas, and how are their teachings related to each one's life as a worshiper in a complex religious community? Questions like these have occupied my own study of Ramanuja and his successors. While many valuable contributions to an outsider's understanding of Ramanuja and his tradition have been made in the last fifty years, no consensus has been

JOHN B. CARMAN, Parkman Professor of Divinity and Professor of Comparative Religion Emeritus at Harvard Divinity School, spent his early childhood in India before coming to the United States for his secondary and higher education (A.B. from Haverford College, B.D. and Ph.D. from Yale University). Before coming to Harvard in 1963, he spent five years in India, four of them as a Research Fellow of the Christian Institute for the Study of Religion and Society. He is the translator of W.B. Kristensen's Dutch lectures on phenomenology of religion (The Meaning of Religion), the author of The Theology of Ramanuja, and Majesty and Meekness: A Comparative Study of Contrast and Harmony in the Concept of God, and co-author of Village Christians and Hindu Culture (with P.Y. Luke) and The Tamil Veda (with Vasudha Narayanan). Currently, he is working on a book attempting a Christian theological interpretation of Christian-Hindu encounter. 
reached, and a wide gap remains between such outside scholarship and the traditional view of Ramanuja by his followers.

We might seem to make more progress by sticking to a comparison of the respective concepts of "loving God". While I shall make a few comments along this line, it should be obvious that "loving God" is so central a concept that it depends on a total interpretation of both thinkers. Moreover, it is a concept relating to religious practice as much as to theory, or it may be a fundamental stance underlying both theory and practice. In any case, the three papers present different conceptions of "loving God" and raise a number of issues that need to be discussed in an interreligious comparison.

Tinu Ruparell's paper suggests, but does not pursue, a comparison between Ramanuja and the two Western philosophers he is comparing, Plato and Leibniz. It is, therefore, not a comparison of Hindu and Christian teachings or practice. He does, however, bring up a number of important issues in such comparison. The first is the definition of the topic itself. "The love of God" may mean human beings' love for God (i.e. "loving God"), God's love for human beings and other creatures, and/or the mutual love within the Divine Trinity (perhaps comparable to love between Vishnu-Narayana and Sri [Lakshmi], or possibly among the Lord and all three of his divine consorts). The Christian tradition generally uses the same terms for love in both directions, whereas the Hindu tradition has a range of terms. The Hindu term bhakti, which western scholars use most often in the context of discussing "loving God," applies only to human love for God. Should we limit our topic to bhakti and its Christian equivalents or also discuss the ways in which the Lord. expresses love for his devotees or even for all finite beings?

A second issue Ruparell's discussion highlights is the relation of physical to spiritual love. As he interprets Plato, in three of the Dialogues, Socrates expounds "on the "art of love' (ta erotica)," making a play on the similarity "between the noun eros and the verb erotan (meaning to question)." Ta erotica thus means for Plato the love of wisdom (philosophia), and the "sexual relationship between older men and young teenage boys" is drastically changed from bodily love to "heavenly, Uranian love, whose object is the soul." Through a relentless questioning, those involved in homosexual love come to "see our natural beloved as but one form of the beautiful, and that it is the Form of beauty within our love which is the real prize."

I cannot judge how cogent is Ruparell's interpretation of Plato. What strikes me is the drastic shift from a physical to a spiritual (or at least intellectual) interpretation of love. Is there a similar shift or a similar ambiguity in Christian and Hindu views of loving God? Both Vedantic Hindu and monastic Christian views of loving God would, at first glance, seem to make an even more drastic distinction than Plato's between physical and spiritual love, the former tying one to the material world, the latter leading one to transcend it. When we look more closely, however, we are struck by the powerful metaphors of physical love that are used to express the passion of spiritual love, both in yearning and in fulfillment.

For South Indian devotional poets and sometimes also for later commentators, the physical is more than a metaphor: both the human devotee and the Divine Lord yearn to possess one another's physical bodies. Christian theologians insist that the physical relationship is intended as a metaphor. Nevertheless, human love for God can express itself in very emotional. ways that may be experienced as an elevated or purified form of physical yearning and physical delight.

In her paper, Archana Venkatesan refers to the bhakti poets transforming the courtly romances of earlier Tamil secular poetry, many from a woman's loving a human hero to a woman loving a divine hero. The woman passionately in love with a masculine god is seeking a union that is physical as well as spiritual. According to Friedhelm Hardy's interpretation, it is just that quest that dooms the devotee to permanent separation from her divine lover, for, Hardy maintains, such bodily union between finite creatures and an infinite deity is a metaphysical impossibility. What he considers the genuine experience of these Tamil bhakti poets is therefore an anguished separation; poetic descriptions of union with God are mere 
flights of fancy. Hardy considers that Srivaishnava commentators have removed the metaphysical difficulty but also the poetic power by completely spiritualizing the devotional relation in a Vedantic "takeover" of Tamil bhakti.

Venkatesan seems to be following Hardy's interpretation, but she limits herself to the most extreme moment of alienation between the divine hero and his woman devotee, who accuses him of destroying her womanhood. Why should this angry response to human separation from the divine hero be the most important or even the only genuine expression of Tamil bhakti? Early bhakti had poetic precedents in earlier Sangam poetry, but it also had a contemporary setting in a community attached to the divine images in specific temples. The poems need to be read verse by verse, but also as part of a larger corpus, as well as in a communal context.

There is a shift in later Srivaishnava theology and practice from the theology expressed by the poets, but it is a complex shift that translates rather than denies the movement back and forth between the physical and the spiritual and between separation and union. The various forms of human love - loving the Lord as a mother loves her baby (literally, as the mother cow loves her newborn calf, vatsalya), as the loyal servant loves her master or mistress, as a friend loves a friend, or as a woman's passionate love for her lover or husband - all serve as metaphors so powerful that they are considered to function for the poet-saints themselves as more than metaphors.

Whether or not Ramanuja commented on the Tamil hymns, that poetic expression of devotion lies behind his own more abstract definition of devotion and his frequent devotional invocations in his Sanskrit writings. Similarly, I suggest, a full understanding of Thomas Aquinas as a religious person engaged in "loving God" needs to take into account the bridal imagery of the Song of Songs and its commentaries as well as the parental and regal imagery of the Psalms.

I agree with Ganeri that the key to Ramanuja's understanding of the "knowledge and love of God" is his concept of the relation of the sheshi and the shesha, which Ganeri translates as "principal" and "accessory." This is one of three facets of the central metaphysical relation, that between the self and its body. It is important to note that while the finite self shares the essential qualities of the Divine Self, those qualities are finite, and as part of the body of the Infinite Self, the finite self is defined by three asymmetric relationships. The finite self is completely supported by the Infinite Self, and it is internally controlled, though less completely, by the Infinite Self. The third relationship is more complicated; it is that of owner and owned or master and servant (or slave), but the servant is not simply the subordinate; he or she is defined as one who "contributes some excellence" to his or her master.

The service of the devoted servant of the Lord is called kainkarya, which comes from the name of the personal attendant who serves his master, "What may I do for you?" All finite beings are metaphysically "slaves" of the Lord, but only those who are conscious of their relationship can enjoy their position as devoted servants. Their love is not only a yearning for union with the Lord; it is a conscious "contributing of some excellence" to the Infinite Lord. This vision of God can only be approached in this earthly existence, not fully realized, but the service expressing their love anticipates the "eternal service" Narayana's devotees can look forward to after this life, when they will serve him in his heavenly realm.

Ganeri therefore rightly concludes that this knowledge that the finite self has as its goal is both the knowledge of God and "its nature as accessory." Since God both transcends and is embodied in all finite reality, the knowledge of the finite self's relation to God is an integral part of the knowledge of God. What is striking in Ramanuja's view of human love for God is that all three aspects of all finite reality's relation to God (including "every blade of grass") are deeply felt by the devotees. All reality is supported by God, but devotees are so conscious of divine support that they feel they cannot live without being aware of that support. Likewise God is present in all finite selves as their inner controller (antaryamin), but devotees have consciously turned over the control of their lives to Lord Narayana. Finally, as observed above, the service to God that is the obligation of all 
finite reality becomes for devotees their own distinctive contribution to the glory of the Lord who, paradoxically, wants for nothing, since his desires are already fulfilled (satyakama, satyasankalpa).

I am struck by the similarity of Ramanuja's statement of the devotee's goal to Aquinas' vision that "the sole and final happiness of a rational being is the loving contemplation of God." In many places, both Aquinas and Ramanuja emphasize the natural tendency of all things to realize their inherent nature, which is to love both the good that is their created (or inherent) nature and the God who has created (or animated) the finite creation. There are other sources for both theologians, however, that put more stress on the "fallen" nature of the finite world and the steps that God has taken to overcome that fallenness. As Ganeri presents him, Aquinas sees the divine grace given through "the saving effects of the life and death of Christ" both as healing human nature from its fallen status and elevating "it to higher capacities." Ganeri does not, however, note what seems to me the corresponding doctrine in Ramanuja's teaching, most eloquently stated at the end of his introduction to his commentary on the Bhagavadgita.

Lord Krishna revealed the discipline of devotion to Arjuna while taking a mortal form in order to help the universe. Overwhelmed by maternal love for his devotee, the Lord became the charioteer for Arjuna's war chariot in order to be witnessed by all the people. The human descent of the Lord of the universe is thus both to teach his human friend and to display his attractive bodily form to human beings. Divine revelation is motivated by love; it occurs through both verbal communication and physical beauty eliciting human love, and it has the goal set forth in the Vedanta, which, negatively expressed, is moksha, deliverance from the bondage of this world, and positively expressed, the attainment of the Lord himself. Later in his commentary Ramanuja paraphrases Krishna's explanation of why he descended to earth as follows: "Because of supreme compassion and love for my devotees in order to become a refuge for all." It is divine compassion for all and maternal love (vatsalya) for his devotees that elicits human love in response, as love that is spiritual but with a suggestion of physical attraction to the Lord's beauty. Whether physical or spiritual, this is a bodily connection, between the body of the devotee and the incarnate body of the Lord (in the past, in his avataras; in the present, in his consecrated images) and the connection is strong enough to dissolve the devotee's accumulated karma from previous lives, though the physical body surrounding the finite self prevents the full union with the Lord, the unobstructed vision that must wait until after this life.

A full comparison of Ramanuja and Aquinas should include a discussion of their differences as well as their similarities. This is the case whether or not the comparison is in the service of an interreligious dialogue. If it is, then it is incumbent on the participant to decide whether the differences are so fundamental as to make further discussion pointless. Clearly that depends on what is considered the point of such dialogue. In my view, its first aim should be greater understanding, and only if there are differences that make discussion impossible should the effort at mutual understanding be discontinued. However, there are many who consider the recognition of important similarities to be crucial to dialogue, the aim of which is more clearly to establish their common ground. Even with such a view of dialogue, differences can be important in all the participants' reflection on the significance of the differences for their own faith. In Ganeri's words, it is "a matter of how the theological imagination is inspired and enriched through the ideas and images to be found in Ramanuja's account." $\mathrm{He}$ has tried in his conclusion to suggest such enrichment with respect to "Ramanuja's concept of the principal and accessory within his embodiment cosmology."

Ganeri's comparison gives the impression that both the Thomist and the Srivaishnava traditions express human love of God in individual terms. Both Western philosophy and the Vedanta do tend to talk about the human relationship to God in individual terms, and modern Western thought may be more emphatically individualistic. A balanced presentation of Christian theology must give equal emphasis to the communal nature of human love of God, especially when describing 
the liturgical expression of love. The New Testament metaphors likening the Christian community to both the "body" and the "bride" of Christ express this communal understanding of the Divine-human relation. In recent years, some Christians have contrasted the communal character of their faith with what they see as the individualistic character of Hindu worship and meditation. While there are some important differences, the community that Ramanuja's followers represent is as important to them as the church is for Christians, even though they do not refer to their community as body or bride.

In her paper, Archana Venkatesan refers to the poet-saint Andal speaking in different voices, that of the love-sick heroine, and that of the gopis, the cowherd girls of Lord Krishna's youth. While the individual voice may be closer to Andal's own experience, her poetic identification with the gopis in the context of liturgical dance is also important. Her own identification by the later tradition as the Bride of God may be a role model for the individual devotee; it is certainly a way of linking Andal's unique experience with that of the whole community of Lord Narayana's devotees. We can see a similar back and forth between both individual and communal devotion in the hymns of Nammalvar. Even if Ramanuja did not comment on those verses himself, (and I am inclined to believe that he did), the ethos of a community reciting and remembering Nammalvar's complex loving relationship with Lord Narayana lies behind his own life and his leadership of the Srivaishnava community. This community, in its communal life, anticipates the eternal love between the devotees and their Lord when they reach his heavenly abode.

Taking these three papers together, we see that they offer suggestive insights on a topic that we choose to consider comparatively: loving God, both as an essential characteristic of being human and as related to Divine initiative and response. We see how difficult it is to place specific texts within an appropriate communal context. When comparisons involve trying to relate traditions that differ widely with each other and that also diverge widely within themselves, we need to attempt a fair comparison. However, at some point we need to consider where we ourselves stand. Is this for us only an academic comparison, or does it also involve our participation in a complicated and ongoing dialogue? 